\title{
ON THE COVER
}

\section{Annie’s Wake by Susan Oomen}

Portions of the following are based on an interview with the artist on January 31, 2015.

Susan Oomen, whose summer-evocative Red Doors II served as cover art for the May-June 2015 issue of American Psychologist, has focused her oil painting on water themes for the past 5 to 10 years. Living in the idyllically named hamlet of Utopia in southeast Ontario, Canada, Oomen's paintings have been exhibited throughout Canada in both public and private collections across North America.

The painting on this month's cover, Annie's Wake, has an "over-determined" title, to use a psychoanalytic concept. Following some years of painting stark winter scenes, Oomen decided that "there comes a point where the subject becomes repetitive, you've solved the technical challenges and explored the theme enough times. These winter scenes had always given me a sense of calm, but I didn't feel that way anymore. I felt I needed to move on, get back to color and lots of paint."

On canoe excursions, Oomen found a new focus: "In the beginning, it was about seeing something new-color on water, the ways that color breaks up and becomes abstract. I was also taken by the misty images. Things are sharp and colorful close to you; as you go back, things become more dispersed and you can barely make them out."

Oomen considers herself a thematic painter, regardless of the particular types of images she studies: Her art is about the continuing human search for calm and peacefulness. Water lends itself to this exploration: "Sometimes when you are going through a difficult time, you keep in mind this space — an image of a lake — that is peaceful. I think people identify with these universal images. Life is hectic and stressful but on these waters, we are getting away from the stresses. Here, in these personal spaces on or near water, nothing changes .... One has a sense of floating."

In addition to the universal, this painting references a particular person and a specific moment in time: Oomen and her husband took part in a multiday canoe trip in Algonquin Park, a 3,000-square-mile provincial park in central Ontario whose interior is accessible only by canoe or on foot. (Algonquin Park also served as a favorite painting ground for Canada's iconic artists of the post-First World War period, known as the Group of Seven.) Their expedition guide was named Annie. At the manifest level, then, the painting's title refers to this guide and the group's explora- tion of nature in the wake that Annie's canoe created. More symbolically, though, Oomen was taken with the idea of a woman paddling a canoe on her own, strong and unafraid of where she is going. She is managing well, showing courage-and leading others.

The daughter of Dutch émigrés and a middle child with 10 siblings, Oomen grew up on an Ontario farm, supported in her artistic interests by family and friends. She singles out her maternal grandfather as talented in a number of ways: Although a farmer, he was a person of many interests, especially bread making. His attitude, that one's children can do anything they set their minds to, became especially important in the family's life: Oomen's father died when she was 17 . Her mother had been a farm wife, without a car or a job. When confronted with the reality of needing to care for the children and the farm, she followed in her father's wake, making use of her widow's insurance money to open a bakery in her home. Over the years, Anna Oomensometimes called Annie by her friends_- became something of a legend in the nearby city of Kingston.

The "Annie" of the painting thus refers to Oomen's mother as well as the canoe guide. Oomen greatly admires the way in which her mother rose to the challenges of widowhood.

At an even deeper level, Annie's Wake was painted around the time that Anna Oomen moved to a nursing home: "It was a really difficult time for her-and for all of us. What I had in mind was what she had created, what she's left behind, in her wake." Unarticulated was the recognition that Anna Oomen was nearing death. At some point, there would be a wake for her mother, a time when memory, peace, and calm would be all that was left. (Anna Oomen died a few months after this interview. In her wake, the artist reflected, her mother left behind 11 successful children, a farm now shared among a number of them, and memories of her strength and courage.)

In this autumn painting, the canoer paddles toward the mist, balanced in her canoe on still water. She glides through the water, leaning forward and to the side just enough to propel her movement onward.

Kate F. Hays Art Co-Editor 